\title{
Innovasjon som tverrprofesjonell samarbeidslæring
}

Trond Eriksen

En viktig forutsetning for velferdsstaten er de nyvinningene som skaper forbedring og fremskritt på viktige områder. Innenfor helse- og velferdssystemet kan dette være alt fra nye teknologier og behandlingsmetoder til endringer i organisering og praksisutøvelse. Sentralt i dette står innovasjon. Innovasjon kan forstås som utvikling og anvendelse av nye og nyttige ideer. De prosessene som skaper innovasjon, oppstår i møtet mellom ulike kompetanseområder og kunnskapsdomener. Kreativitet og idéutvikling lever der mangfoldet råder. I samhandlingen mellom ulike anskuelser og perspektiver ligger altså mulighetsrommet for innovasjon. Studentene kan i fellesskap realisere potensialet for innovasjon, særlig der undervisningen er tverrfaglig og tverrprofesjonelt forankret.

\section{Innovasjon skal læres}

I forskrift om felles rammeplan for helse- og sosialfagutdanninger beskrives kandidatenes forventede sluttkompetanse gjennom tolv felles læringsutbytter. Ifølge læringsutbytte nummer elleve er det forventet at: «Kandidaten kjenner til nytenkning og innovasjonsprosesser og kan bidra til tjenesteinnovasjon og systematiske kvalitetsforbedrende arbeidsprosesser» (Forskrift om felles rammeplan for helse- og sosialfagutdanninger, 2017). Dette kapittelet har et teoretisk fokus, rettet mot noen 
grunnleggende pedagogiske avklaringer og ansatser på veien mot studentenes ervervelse av dette læringsutbyttet. Et naturlig utgangspunkt for en teoretisk sondering mot læringsutbyttets pedagogiske drivverk er innovasjonsbegrepet i seg selv, og særlig de prosessene som driver innovasjon fremover. Her vil vi se at innovasjon i grove trekk oppstår i møter mellom mennesker som bærer med seg ulike kompetanser og kunnskapsdomener. I slike møter kombineres eksisterende kunnskap, og det åpnes et mulighetsrom der noe nytt kan etableres. Kreativitet og idéutvikling er altså en kollektiv og tverrfaglig prosess i møtet mellom forskjellige perspektiver, og der forskjellige perspektiver mobiliserer forestillingsevnen og muligheten til å rette blikket mot nye og ukjente steder. Det nye både oppdages og skapes i fellesskap. Dermed vil det være naturlig å se nærmere på tverrprofesjonell samarbeidslæring (TPS) som pedagogisk tilnærming til dette læringsutbyttet. De læringsaktivitetene som faktisk finner sted innenfor den TPS-organiserte undervisningen, vil rimelig nok svare til bestillingen i læringsutbyttet. I dette ligger en forventning om studentenes kjennskap til hva innovasjonsprosesser er. Men viktigst i denne sammenhengen er at studentene selv erfarer verdien og betydningen av tverrprofesjonelt samarbeid når innovasjonsprosesser utøves i praksis. Uavhengig av de metodiske og didaktiske valgene som gjøres innenfor rammene av TPS, så drives kunnskapsdeling og kunnskapsetablering kollektivt frem i møtet mellom studentene. Bestillingen som ligger i læringsutbytte nummer elleve, løser altså ut et pedagogisk tilsvar der studentene møtes i kollektive og kreative prosesser på tvers av utdanningenes kunnskapsdomener, med mål om å utvikle nyttige og realiserbare ideer. Innovasjon skal altså læres, og læringen skjer i fag- og kompetanseoverskridende møter. Formålet med dette kapittelet er en teoretisk drøfting rundt noen pedagogiske forutsetninger for realisering av innovasjonsprosesser innen helse- og sosialfagene samt drøfting av verdien i å rigge undervisningsopplegget som TPS. Jeg vil også gi noen enkle eksempler på hvordan dette kan foregå i praktisk undervisning. Men først kan det være på sin plass å se litt nærmere på begrepene som ligger i læringsutbyttet. Her vil jeg sette søkelys på innovasjonsprosesser og tjenesteinnovasjon.

\section{Innovasjon og tjenester}

Læringsutbyttet, slik det er formulert i forskriften, har en åpenbar indre logikk i begrepsrekkefølgen: Først skal kandidaten kjenne til innovasjonsprosesser, 
så kunne bidra til tjenesteinnovasjon. I etymologisk betydning ser vi at ordet innovasjon kommer fra det latinske innovare, det å fornye eller skape noe nytt. Innovasjon er å tenke nytt, men også det å gjennomføre ideen eller tanken i praksis. I Norge defineres vanligvis innovasjon, med forankring hos den østerrikske økonomen Joseph A. Schumpeter (1934), som «en ny vare, en ny tjeneste, en ny produksjonsprosess, anvendelse eller organisasjonsform som er lansert i markedet eller tatt i bruk i produksjonen for å skape økonomiske verdier» (Nærings- og handelsdepartementet 2009, s. 13). Det er vanlig å skille mellom tre typer, eller nivåer, av innovasjon:

- Radikal innovasjon: Her er det snakk om innovasjoner som bringer fram noe helt nytt, noe som ikke har eksistert tidligere, og som snur opp ned på både gjeldende marked eller tjenesteyting. Plogen i jordbruket, forbrenningsmotoren, symaskinen, elektriske ledere, røntgen, kredittkortet, internett, mobiltelefon og fiskeoppdrett er eksempler på radikal innovasjon, nyskapninger som ofte fører med seg økonomiske, sosiale og samfunnsmessige endringer (Goffin \& Mitchell, 2005, s. 15).

- Inkrementell innovasjon: Dette er de kontinuerlige, gradvise og moderate endringene på eksisterende produkter eller tjenester, eksempelvis utvikling av felleski, nye utslippsreduserende flymotorer, landbasert fiskeoppdrett eller det at fartsbøter kan leveres på SMS. Det er altså snakk om forandring, forbedring og utvikling som en pågående prosess (Goffin \& Mitchell, 2005, s. 15).

- Distruptiv innovasjon: Her har vi de nyvinningene som endrer eller forstyrrer det etablerte markedet. Eksempler på dette er digital fotografering, som fikk gigantselskapet Kodak til å kollapse, eller at strømmetjenester som Netflix og Spotify velter om på den tradisjonelle mediebransjen (Christensen, 2015, s. 157$160)$.

Vi tenker vanligvis på innovasjon som produktutvikling, og at disse nye produktene finner veien ut til et marked. Her kan vi se for oss utviklingen av nye helseteknologiske artefakter som påvirker, endrer og forbedrer ulike tjenester innenfor helsevesenet. Men innovasjon er også utvikling av service og tjenester. I forskriftens læringsutbytte er det nettopp tjenesteinnovasjon studentene 
skal kunne bidra til. Til forskjell fra en vare, eller et produkt, så kjennetegnes en tjeneste ved at den er:

Immateriell: En tjeneste er utførelse av en handling, og ikke en fysisk gjenstand som et produkt er. Eksempelvis vil en stomipose være et konkret produkt, mens veiledningen og samtalen rundt det å leve med stomi er en tjeneste.

Heterogen: Fysiske produkter kan lages i et mangfold av identiske eksemplarer, men tjenestene som tilbys og utøves sammen med produktet, vil variere. Dette henger sammen med to forhold: 1) Samme produktet kan ha ulike leverandører, og hver leverandør har ulike tjenestetilbud knyttet til produktet. 2) Tjenester er utførelse av handlinger, og handlinger gjøres av mennesker i relasjon og med hensikter. Dermed vil enhver veiledningssamtale rundt bruken av stomiposer være et unikt møte som eksisterer der og da. Selve tjenestetilbudet kan være formalisert, men vil altså framstå som et mangfold gjennom den faktiske utførelsen av tjenesten.

Uatskillelig: Tjenesten produseres, leveres og forbrukes på samme tid. Slike økonomifaglige begreper kan umiddelbart framstå som noe fremmedartet i helse- og sosialtjenester, men her dreier det seg om at en veiledning faktisk produseres og leveres idet den finner sted. Det er en levende prosess der pasienten tar til seg veiledningen. Stomiposen er allerede produsert, levert og forbrukes kun ved bruk.

Ikke-varig. Det at tjenester er ikke-varige, kan forstås i to sammenhenger: 1) Tjenesten kan være betalt og tilgjengelig, men ikke brukt. Dette kan eksempelvis være et hotellrom man har betalt for, men av en eller annen grunn ikke benytter. Det kan også være sykepleieren som ikke deltar på veiledning i bruk av stomipose. 2) Tjenester er handlinger, og handlinger kan ikke lagres og spares til en annen gang. Det gjelder for eksempel veiledning i bruk av stomiposer. Når veiledningen er over, så eksisterer den ikke lenger. Hver veiledningsrunde er en unik handling som ikke kan kopieres til neste runde. I begge sammenhenger vil tjenester som ikke benyttes, miste sin verdi (Zeithaml, Parasuraman \& Berry, 1985, s. 34). 
Tjenester er altså handlinger som sparker liv til produktet, som gir verdi, innhold og betydning utover produktets iboende verdi (pris) og bruksverdi. Begrepet tjenesteinnovasjon ble introdusert av den engelske psykologiprofessoren Ian Miles. Han pekte på at verdensøkonomien endret karakter, særlig utover på 1980-tallet, der en stadig større del av verdiskapningen forflyttet seg fra en tradisjonell produksjonsvirksomhet til service- og tjenesteyting. I tillegg til dette kom en langvarig og stor vekst i det offentlige tjenestetilbudet. Miles viser deretter hvordan tjenester er preget av relasjoner framfor transaksjoner, noe som betyr at tjenester er relasjonsintensive, og at god tjenesteutøvelse forutsetter mellommenneskelige ferdigheter. Dette er særlig aktuelt innenfor personsentrerte tjenester som helse, utdanning og velferd. Tjenester kjennetegnes også av at de er informasjonsintensive, noe som igjen fordrer tilrettelegging for god flyt gjennom rutiner og relevante plattformer for deling av informasjon og kunnskap (Miles, 1993, s. 657). Her kan det være interessant å merke seg hvordan utviklingen av ny teknologi driver fram innovative løsninger i informasjonsintensive tjenester som er knyttet til helse- og sosialsektoren. Et eksempel på dette er den nettbaserte portalen www.helsenorge.no, som primært skal gi økt brukermedvirkning og medbestemmelse samt avlaste helsevesenets administrative støttefunksjoner. Uansett, helse- og sosialfaglige studenter skal altså kunne bidra til innovasjon innenfor det Miles beskriver som personsentrerte tjenester. Hva tjenestene konkret består av, er regulert og definert i lovverk som helse- og omsorgstjenesteloven, helsepersonelloven, spesialisthelsetjenesteloven, folketrygdloven og pasient- og brukerrettighetsloven, alle med tilhørende retningslinjer og veiledere. Hvordan disse tjenestene utøves til beste for både brukere og profesjonsutøvere, er under stadig endring. Til dette skal studentene være faglig skodd på en slik måte at de aktivt kan bidra til utvikling. Dermed blir neste skritt å se på hvilke prosesser som fremmer innovasjon.

\section{Innovasjonens forutsetninger}

Ifølge Andrew Hargadon og Beth Bechky (2006) henger innovasjon og kreativitet tett sammen. Kreativitet er en egenskap som utfoldes og blomstrer i møtet og samhandlingen mellom ulike mennesker, mellom ulike kompetanser, perspektiver og løsningsorienteringer. Kreativitet er med andre ord et sosialt samspill der mangfoldet utspiller seg. I dette ligger tanken om at 
kreative løsninger etableres ved å kombinere eksisterende kunnskap, altså en sosial interaksjon der det nye skapes i møtet med det som allerede er. Hva som er et problem, og hvordan problemet møtes og løses, er et produkt av kollektive prosesser der individenes bidrag både former og gir ny mening til hverandre. Disse kreative prosessene defineres til det å sette gamle ting i nye kombinasjoner, og nye ting i gamle kombinasjoner (Hargadon \& Bechky, 2006, s. 485-487). Potensialet for kreativitet finnes altså i det polyfone, i kontraster og polaritet. Samtidig må mangfoldet av stemmer møtes i settinger preget av interdisiplinært samarbeid og integrasjon. Det er slik mangfoldets kreative potensial forløses. For å beskrive disse kreative prosessene i innovasjon brukes ofte jazzimprovisasjonen som metafor. Musikerne i et jazzorkester balanserer mellom musikkstykkets komposisjon og kreative kombinasjonsmuligheter som ligger i de individuelle ferdighetene. Det musikalske avviket som ligger i improvisasjonen, beriker innenfor musikkstykkets rammer. Forstyrrelser skaper spenning og dynamikk, det balanseres mellom divergens og konvergens, harmoni og disharmoni avslører ukjente veier i musikken, og feil og mangler skaper nye muligheter. Med andre ord: Det oppstår endring og nyskapning i møtet mellom det ulike (Laing \& Bacevice, 2013, s. 39). Keith Sawyer og Stacy DeZutter (2009 s. 81-83) er inne på det samme når de viser hvordan kreative produkter vokser fram gjennom grupper og nettverk som samhandler. Det tenkes og reflekteres i fellesskap, de kognitive prosessene distribueres og gjøres synlige, åpnes for nye responser og reaksjoner. Resultatet av en slik felles aktivitet er at utfallet er uforutsigbart. Ingen vet helt sikkert hvor man ender opp til slutt. Aktiviteten preges også av et slags øyeblikkets logikk, der hver handling, hver respons og hver ytring er en direkte følge av den forutgående. Denne grunnleggende sosiale forståelsen av kreative prosesser korresponderer med Mikhail Bakhtins dialogiske livsanskuelse, der det «å være vil si å ha dialogisk samkvem», og at «to stemmer er et minimum for livet og væren» (Bakhtin, 2003, s. 197). Mening oppstår når to eller flere stemmer kommer i kontakt med hverandre, når stemmen til den som hører, responderer på stemmen til den som ytrer seg. Idet noen ytrer seg, det være seg muntlig, skriftlig eller i form av kunstneriske uttrykk, bærer ytringen med seg både mening og intensjon. Den som ytrer seg, forsøker altså å plassere sitt eget konseptuelle system, eller begrepsarsenal, innenfor lytterens forståelsesrammer. Lytteren på sin side møter ytringen med en aktiv og responderende holdning og betoner denne med egne meninger og intensjoner. Ulike stemmer møtes, og nytt meningsinnhold oppstår i en evig runddans der alle ytringer 
fylles med gjenklang av hverandre (Bakhtin, 1994a, s. 76-77). Gjennom dialogiske relasjoner ligger vi alltid på grensen av det som er, og det som er i ferd med å bli. Ny forståelse, nye sammenhenger, nye perspektiver, nye løsninger og nye ekspressive uttrykk realiseres gjennom dialogen, gjennom møtet mellom ulike konseptuelle systemer. I denne flerstemmigheten ligger potensialet for både kunnskapsdeling og etablering av ny kunnskap. Til grunn for dette ligger et sosiokulturelt perspektiv på kunnskap, «der mening blir skapt i interaksjonen eller dialogen mellom den som talar og den som høyrer, den som skriv og den som les (Dysthe, 2001, s. 66). Kunnskap er med andre ord noe den enkelte gjør til sitt eget, og som stadig utvikles og endres gjennom dialogiske relasjoner. Med en rask og foreløpig oppsummering ser vi at det sosiale samspillet mellom ulike mennesker med ulike konseptuelle systemer generer ny kunnskap og nye løsninger. Når både kunnskap og innovasjon skapes og formidles kollektivt, vil tverrprofesjonell samarbeidslæring være en relevant tilnærming. Neste steg blir da å se på hvordan en kollektiv organisering av undervisningen ligger til grunn for innovative prosesser.

\section{Det innovative og det flerdisiplinære}

I samsvar med forskriftens læringsutbyttebeskrivelse retter vi altså blikket mot personsentrert tjenesteinnovasjon, en type innovasjon der det nye utvikles fra noe som allerede finnes (inkrementell innovasjon). Sentralt i dette står kunnskapsmobilitet og kunnskapsbygging, det at eksisterende ressurser på ett område kan ha verdi og funksjon i nye kombinasjoner andre steder (Hargadon, 2002, s. 44) I helse- og sosialprofesjonene er odontologi og barnevern (tannhelse som indikator på omsorgssvikt), psykologi og fysioterapi (psykomotorisk behandling), ernæring og sykepleie (diett og ernæringsstatus innen geriatri, kreftbehandling, rusomsorg etc.), ergoterapi og sosialt arbeid (sosial deltakelse for mennesker med nedsatt funksjonsevne) samt ernæring og psykologi (spiseforstyrrelser) noen eksempler fra en lang rekke tverrfaglige konstellasjoner. Enkelt sagt illustrerer disse eksemplene prinsippet om at kunnskap og kompetanse innenfor ett domene aktualiseres innenfor et annet. Hvis vi går en del år tilbake i tid, kan vi se for oss hvordan tannlegenes kunnskap og kompetanse ikke ble tenkt som relevant for barnevernet, og vice versa. Både tannleger og barnevernspedagoger var i så måte bærere av faglige og domenespesifikke skjema og skript som definerte roller, legitimerte 
handlinger, etablerte fagkultur og skapte tradisjoner (Giddens, 1979). Som profesjonsutøvere var de med andre ord deltakere i faglige domener med relevant, men ukjent kunnskap for hverandre. Samtidig ser vi at slike domener, med en tett indre faglig integrasjon, også representerer det mulighetsrommet der eksisterende ideer kan kombineres i nye løsninger. Her er det ikke kun snakk om distribusjon av kunnskap mellom ulike fagtradisjonelle domener, men dypere og mer eksistensielle endringsprosesser for individer, grupper og tradisjoner samt for bruken av artefakter. Ved å bevege seg mellom ulike domener, la ulike kunnskaps- og erfaringsbaser møtes, så kan perspektiver, holdninger, preferanser og disposisjoner endres radikalt (DiMaggio, 1997, s. 280). En titt på nettbaserte presentasjoner av både helse- og sosialfaglige fakulteter viser et mangfold av ulike fagtradisjoner, hver av dem med sin egen kjerne av kunnskap, kompetanse og historikk. Ut fra disse fagtradisjonene skapes det profesjonsutøvere som bruker sin kunnskap i flerfaglige organisatoriske enheter, eksempelvis et sykehus, eller i et nettverk med andre kunnskapsdomener, eksempelvis mellom kommunen og klinikker i spesialisthelsetjenesten. Organisasjoner som har et bevisst og aktivt forhold til kunnskapsmøter og kunnskapsdeling mellom ulike profesjoner, bereder grunnen for læring og gir dermed ny mening til eksisterende kunnskap og erfaringer man bringer med seg fra egen profesjonsutøvelse. Dette er uttrykk for en kollektiv kreativitet der tankeprosesser deles og former hverandre i dialogiske relasjoner. Gjennom disse læringsprosessene akkumuleres et felles kunnskapsarsenal om ressurser og problemer innenfor ulike domener, og tidligere kunnskap kan transformeres til nye og innovative produkter, prosesser og tjenester (Hargadon, 2002, s. 43-45). Stikkordet her er altså tverrprofesjonelle møter som plattform for innovasjonsprosesser. Skal dette realiseres i praktisk profesjonsutøvelse, må den tverrprofesjonelle samarbeidskompetansen også bevisstgjøres og øves innenfor utdanningsinstitusjonene. Dermed er det fruktbart å rette blikket mot tverrprofesjonell samarbeidslæring.

\section{Tverrprofesjonell samarbeidslæring}

Tverrprofesjonell samarbeidslæring (TPS) er langt på vei et selvforklarende begrep. Vi ser at det dreier seg om læring som et samarbeidsprosjekt, og at ulike profesjoner er representert i dette samarbeidet. I den såkalte 
Samspillsmeldingen defineres TPS som «en læringsform der studenter fra ulike profesjonsutdanninger lærer sammen og får innsikt i andres kompetanse og dermed også bedre forståelse av sin egen» (Kunnskapsdepartementet, 2011, s. 69). Ut fra disse definisjonene kan vi lese inn to grunnpilarer i TPS:

1. Møtet mellom studenter: Studentene må rimelig nok møtes, og møtene må være tilrettelagt for dialogiske relasjoner som er preget av en åpen og utforskende holdning.

2. Studentene må bringe med seg profesjonsspesifikk kompetanse i møtet.

Hva som tematiseres, hvem som tematiserer, hvem som er med i møtene, hvor møtene finner sted, og hvordan møtene organiseres, er pedagogiske spørsmål som bevisst må reflekteres over i forkant. Eksempelvis kan temaet, eller undervisningens objekt, være tverrfaglig kreftbehandling. Da vil det være naturlig å la studenter fra medisin og sykepleie (medisinske/medikamentelle tiltak), radiografi (stråling), ergoterapi (tilrettelegging av hjem og arbeidsplass), fysioterapi (trening) og psykologi (angst, sorg og mestringstrening) møtes i en kollektiv kunnskapsgenerator. Den pedagogiske gjennomføringen av det tverrprofesjonelle møtet kan ta form av felles refleksjoner rundt praksiserfaringer (Dewey, 2008; Lave \& Wenger, 1991), problembasert læring (Pettersen, 2017) eller mer pensumrettet gruppe- og seminarundervisning (Dysthe, 1993; Rommetveit, 1996; Pettersen, 2005). Uavhengig av den faktiske læringsaktiviteten kan vi altså forstå møtet som den ene av to grunnpilarer i TPS. Ifølge den tyske pedagogen og eksistensfilosofen Otto Friedrich Bollnow innebærer et møte «alltid at mennesket støter på noe som det ikke har beregnet eller kunne beregne, noe som er ganske annerledes enn han ventet seg i sine tilvante forestillinger, og som tvinger han til å orientere seg på nytt» (Bollnow, 1969, s. 107-108). Her aner vi møtets refleksive og samtidig umiddelbare karakter. I møtet med hverandre inviteres studentene til ettertanke og fundering, over seg selv, sine fremtidige medarbeidere og sin egen gryende profesjonstilhørighet. Slik representerer møtet et mulighetens landskap som bærer bud om brudd med fortiden og varsel om noe nytt. I Bollnow sin eksistensfilosofiske språkdrakt kan møtet framstå som en radikal omveltning av egen forståelseshorisont. Det kan møtet også bidra til, men det sentrale er møtets iboende mulighet til endring, til det å gi andres kompetanse og livserfaringer innpass i egen forståelseshorisont, innpass i eget begreps- og 
fortolkningsapparat. Dermed vil studentene, ideelt sett, kjenne seg selv og sin egen og andres profesjon på en ny og annerledes måte etter å ha møtt hverandre i en tverrprofesjonell undervisningssetting. Videre vil god samhandling i tverrprofesjonelle grupper åpne opp for studentenes metalæring. Dette er et poeng det bør dveles litt ekstra ved. Her er det snakk om studentenes bevissthet om egen læring og tenkning, en forståelse av den læringen som ligger i det å lære av, med og om hverandre. I de tverrprofesjonelle møtene forsynes studentene med det Jerome Bruner kaller bevissthetsteori, altså hvordan studentene forstår sin egen læring og deltakelse i denne (Bruner, 1997, s. 87, se også Flavell, 1979; Ogden, 2004). Ved å samhandle og samarbeide utvikles også samarbeidskompetansen, eller det som i Samspillsmeldingen kalles evnen til tverrprofesjonelt samarbeid (Kunnskapsdepartementet, 2011). Forenklet sagt så avler samhandling mer samhandling, og ved å praktisere samhandling så blir studentene dyktige til nettopp det (Lewin \& Reeves, 2011, s. 16001602). Den andre grunnpilaren i TPS kan lokaliseres til den profesjonsspesifikke kompetansen som studentene bringer med seg til de tverrprofesjonelle møtene. Dette dreier seg om den «kompetansen som en profesjon har og som de andre ikke har, det vil si den kompetansen som skiller ulike fagpersoner fra hverandre. Kjernekompetansen reflekterer hovedfokus i den enkelte profesjons fag, det vil si det denne profesjonen er best på» (Willumsen, 2016, s. 43-44). Det er dette Hargadon (2002, s. 62) definerer som innovasjonens råmateriale, den domenebaserte kunnskapen og erfaringen som gjennom tverrprofesjonelle møter danner grunnlaget for nye løsninger. Det samme kan sies om TPS. Studentene bærer med seg kunnskap, holdninger og erfaringer som presenteres og møtes i tverrprofesjonelle settinger med det formålet at noe nytt skal etableres. Læringspotensialet ligger med andre ord i de forskjellige kunnskaps- og kompetanseområdene som møtes og bryner seg på hverandre (Bakhtin, 1986; Bakhtin, 1994a; Vygotskij, 2001). Så er det jo slik at studentenes kunnskapsbasis utvikles over tid, og at profesjonsidentiteten og egen rolleforståelse etableres parallelt med økt kunnskapsbasis. At dette er på plass tidlig i et studieforløp, kan ikke forventes, men tverrprofesjonelle møter kan bidra til økt forståelse og trygghet på egen profesjonsidentitet i møte med andre. Men kanskje viktigst av alt er samarbeidskompetansen som både utvikles og styrkes i akkurat tverrprofesjonelle møter. Samarbeidskompetansen muliggjør en frigjøring av den domenespesifikke kunnskapen og ligger sånn sett til grunn for organisasjoners kapasitet til å skape ny kunnskap på bakgrunn av eksisterende (Cohen \& Levinthal, 1990, 
s. 129). TPS og innovative prosesser består av de samme grunnleggende prinsippene: Det er snakk om bærere av ulik kunnskap og kompetanse som møtes, og at disse møtene skaper noe nytt. Innenfor pedagogisk litteratur kan dette oppsummeres ved hjelp av Bruner, som understreker betydningen av oppsamlet faktakunnskap, samt bevisstheten om at «kunnskap avhenger av perspektivet og at vi deler og forhandler våre perspektiver i kunnskapstilegnelses-prosessen. Man måtte være en hykler dersom man nektet for at vi blir rikere når vi skjønner at det er bånd mellom holdbar kunnskap fra fortiden og det vi lærer i nåtiden» (Bruner, 1997, s. 87). Innovasjon dreier seg om å skape noe nytt, og i dette står ideen sentralt. Neste skritt blir å se på idéutvikling som tverrprofesjonell samhandling.

\section{Ideen}

Begrepet idé har sitt etymologiske utspring i det greske idea, som betyr synlig form eller utseende. Dette er igjen avledet av idein, det å vite eller forstå. En idé kan vise til prinsipper og grunnlagstenkning, som Platons idélære, ideen om menneskerettigheter eller ideen om etikk som læren om moral. Så har vi den mer hverdagslige forståelsen om ideen som en forestilling, en tankevirksomhet og bevissthet om noe, og som leder til handling (Det Norske Akademis ordbok, 2020). Når det kommer til innovasjon, så har den hverdagslige betydningen av ideen størst aktualitet. Så er spørsmålet hvordan ideer oppstår og etableres. Hargadon \& Bechky (2006) og Sawyer \& DeZutter (2009) formidler en kollektiv forståelse av kreativitet og idéutvikling. Hvert enkelt individ bidrar, men den kollektive kreativiteten, de nye ideene, utvikles når perspektiver og erfaringer bringes sammen og gir ny mening til hverandre. Igjen, individene bidrar med «gamle» ideer, den kunnskapen hver og en innehar, og der de kreative øyeblikkene oppstår når «gamle» ideer konfluerer og nye løsninger skapes (Hargadon \& Bechky, 2006, s. 485). Arne Carlsen, Stewart Clegg \& Reidar Gjersvik (2012) har sett nærmere på kollektive prosesser slik de praktiseres i seks forskjellige bedrifter, og har lokalisert noen sentrale kvaliteter ved idéarbeid. Nå skal vi ikke gå inn på hver enkelt av disse i denne omgang, men heller la Kjetil Trædal Thorsen i arkitektfirmaet Snøhetta fortelle om hvordan ideen til Operaen i Oslo oppstod: 
Vi har disse lange samtalene - det er veldig mye snakk. (...). Vi prøver å integrere alle i disse samtalene. Det er en sirkel av samtaler, en felles vandring i referanser. (...) Arkitektur handler om å skape slike felles forestillinger om det som kan bli noe. (...) Det kan være kollektive aha-opplevelser, men de skjer aldri uavhengig av en forutgående analyse. Kunnskap er basis for alt. Det er simpelthen utenkelig å trekke aha-opplevelser ut fra løse lufta (Carlsen, Clegg \& Gjersvik, 2012, s. 17-19).

Trædal Thorsen beskriver her det kollektive aspektet ved innovasjon som en kreativ prosess, og hvordan nye ideer skapes i disse. Samtidig beskriver han også prinsippene for tverrprofesjonell samarbeidslæring. Kunnskap deles og etableres der ulike stemmer møtes, utfordrer og utfyller hverandre. Nye ideer forhandles fram gjennom dialogiske relasjoner, eller det vi husker Bakhtin beskriver som en konstant veksling mellom det som allerede finnes, og det som er på vei til å bli (Bakhtin, 1994b, s. 90-94). Vi kan godt se for oss samme prosesser i en læringssituasjon der sosial- og helsefagstudenter med ulik faglig bakgrunn skal komme opp med en ny idé om hvordan rutiner for samhandling og informasjonsflyt mellom helsesykepleier, fastlege, barnevernstjenesten og barne- og ungdomspsykiatrien kan bedres. Eller et forebyggingsprosjekt mot uønsket kroppspress blant ungdommer der fag som fysioterapi, sykepleie, psykologi og medisin er involvert. Poenget er at det genereres ny kunnskap, nye ideer og løsninger i tverrfaglige møter, og der det kreative potensialet forløses nettopp i tverrfagligheten. Her møtes forskjellige stemmer, et mangfold av kunnskap, holdninger og perspektiver målbæres, og det etableres et felles tanke- og handlingssystem, en felles enhet der ny mening oppstår (Bateson, 1972, s. 287). Det er i disse møtene at ideer skapes og utvikles. Den kreative prosessen kan organiseres på mange måter: idémyldring ved hjelp av tankekart, ABC-metoden, lappemetoden, kreativ skriving, kreativ kafe, flippover-metoden, rollespill, visualisering (moodboard) etc. Det finnes altså en rekke ulike måter å gjennomføre kreative økter på. Dette kan beskrives som lærerens disponible verktøykasse for didaktisk gjennomføring av tverrprofesjonell samarbeidslæring der undervisningens objekt er idéutvikling. Her legges det til rette for at kunnskapen, den kompetansen og de holdningene studentene bringer med seg, kunngjøres og synliggjøres for hverandre. Det som er av særlig interesse i disse idéutviklende prosessene, er det dialogisk relasjonelle forholdet, eller betydningen av at ordene 
vandrer mellom studentene. Bakhtin beskriver hvordan ideene begynner å leve, finner og fornyer sitt verbale uttrykk, skaper nye ideer i genuine dialogiske relasjoner med andre ideer, med ideene til andre (Bakhtin, 1994b, s. 98-99). En idé utvikles, ernæres og realiseres i et dialogisk fellesskap. Ideen som kun eksisterer isolert i en individuell bevissthet, vil sakte, men sikkert avgå en ensom død i mangel på ernærende responser fra omgivelsene. Ideen er med andre ord «a live event, played out at the point of dialogic meeting between two or several consciousness» (Bakhtin, 1994b, s. 98). Med en rask oppsummering ser vi at idéutvikling og idérealisering er kjernen i innovasjon, og at dette skjer i en kollektiv og kreativ prosess der dialogiske relasjoner mellom mennesker fra ulike kunnskaps- og kompetansedomener er det bærende prinsippet. Neste spørsmål blir da om ideen kan se dagens lys uten en forestillende virksomhet. Trædal Thoresen er inne på dette når han beskriver arkitektur som det å «skape slike felles forestillinger om det som kan bli noe». I dette ligger det å se for seg muligheter og alternativer, tenke seg det som ennå ikke er, men som kan komme til å bli.

\section{Det å forestille seg}

Uansett hvilket begrepsinnhold som skal avklares, er det lurt å nøste fra grunnkilden, noe som ofte fører oss til Aristoteles. I sin Poetikken (ca. 335 før Kristus) viser han at litteraturens funksjon ikke er å vise oss hva som har skjedd, men snarere hva som kan skje. Det er med andre ord en invitasjon til leseren, eller teaterets publikum, om å ta stilling til et hvis eller hva om (Aristoteles, 2004). Litteraturens potensial realiseres i dens invitasjon til å lokalisere alternative holdninger, handlinger, strategier, løsninger samt begrunnelser for disse. Med litteraturen som utgangspunkt peker altså Aristoteles mot den menneskelige evnen til å forestille seg noe som ikke er. Hopper vi ca. 2000 år fremover i tid, treffer vi på David Hume. I sin A Treatise of Human Nature viser han til menneskets persepsjon som bestånde av de to kategoriene inntrykk og ideer. Enkelt sagt er våre inntrykk av en umiddelbar, autentisk og mer levende orden enn våre ideer. Vi kan få et inntrykk av å fryse når vi står ute $\mathrm{i}$ kulden, men når vi er inne foran den varme peisen, sitter vi igjen med et svakere og distansert bilde av hvordan det var å fryse. Dette er ideen, eller et mentalt bilde, om å fryse. Ideen er altså en refleksjon av inntrykket. Samtidig har mennesket evne til å skille mellom det som er ulikt. 
Hume eksemplifiserer dette ved et eple. Vi kan ha ideen om et grønt eple og samtidig skille ut ideer om eplets ulike egenskaper, som farge, konsistens og smak. Disse ideene kan blandes og kombineres med andre ideer, noe som gir oss muligheten å skape nye refleksive inntrykk om et blått eple, et eple stort som et fjell eller et eple som smaker lakris. Dette er forestillingsevnen i virksomhet (Hume, 2012, s. 17-23). Ideene bearbeides, omkalfatres og fremstår som nye mentale inntrykk, som igjen lagres i hukommelsen som ideer. Men hvis vi legger en streng rasjonell forståelse til grunn, kan evnen til å forestille seg framstå som både kostnadskrevende og til liten nytte. Det vi forestiller oss, har sjelden systematisk relasjon til det som faktisk er. Uansett hvor hardt jeg forestiller meg en hytte på høyfjellet, så vil dessverre hytta ikke eksistere andre steder enn i min forestilling av den. Men samtidig kan man jo spørre om hytta noen gang kan realiseres i form av konkrete byggevarer og møbler uten en forutgående forestilling om denne? Gregory Currie (1995, s. 141143) er inne på dette når han en smule retorisk spør om hvorfor vi mennesker skal ha utviklet noe så komplekst og subtilt som evnen til å forestille oss, hvis denne evnen ikke har noe positivt formål? Gjennom forestillingsevnen kan vi lage oss mentale hypoteser, eller tankebilder der vi kan se og forstå muligheter som lar seg realisere, og eventuelle konsekvenser. Ja, ved å forestille oss kan vi lære av hypotetiske eksempler som: Hva kan skje dersom jeg løper ut i den trafikkerte gaten uten å se meg for, hva ville jeg gjort hvis huset begynner å brenne, hva skjer hvis jeg låner penger for å bygge hytte på høyfjellet, hvordan kan det være å arbeide som sykepleier, eller hva vil skje hvis jeg takker ja til et stevnemøte? Vi kan med andre ord forestille oss mangt og meget før vi gjør våre valg. Forestillingsevnen står også sentralt i våre møter med andre mennesker, og dermed våre møter med oss selv. Richard Wollheim (1974, s. 172-175) beskriver hvordan forestillingsevnen gjør det mulig for et menneske å se seg selv i relasjon til andre, sette seg selv i den andres plass og gjennom refleksive prosesser oppdage de karakteristiske trekkene som gjør oss til den vi er. Forestillingsevnen og identifisering henger altså sammen. Currie (1995, s. 141-152) tar utgangspunkt $\mathrm{i}$ Wollheim sitt perspektiv når han beskriver hvordan vi $\mathrm{i}$ vår forestilling kan være i den andres posisjon, motta den informasjonen som den andre mottar, og slik forestille oss hvordan vi ville respondert i en liknende situasjon. Vi stilles altså overfor hypotetiske valg som både trigger og krever stillingstakning. Dette er særlig synlig i våre møter med mennesker som står i et etisk dilemma, det kan dreie seg om politikk, offentlig forvaltning, skole og undervisning, journalistikk, religion 
eller helse og omsorg. Vi settes altså i forestilte situasjoner der vi må spørre oss selv hva vi ville gjort, hvilke valg vi ville tatt. Dette er mentale prosesser der vi gis en mulighet til å møte våre egne prioriteringer, vårt verdisyn og våre følelser rundt dette. Her ser vi en klar parallell til Finn Skårderud (2016) der han beskriver mentalisering som evnen til å skille mellom de forestillingene vi gjør oss om verden, og den verden vi gjør oss forestillinger om. Det å forstå at den verden som eksisterer i våre hoder, er våre egne og private forestillinger om verden, og ikke verden per se, betegner Skårderud som en avgjørende sosial kompetanse. En forståelse av at våre egne forestillinger ikke representerer det som er, men snarere vår egen etiske, emosjonelle og kunnskapsmessige refleksjon av det som er, eller kan bli, må sies å være en god startkapital for en mulig kollektiv deling og etablering av kunnskap. Kort oppsummert kan vi si at forestillingsevnen er det å lage seg mentale bilder av hvordan noe kan komme til å bli, hvordan noe kan være annerledes, eller hvordan noe kan oppleves og erfares. Altså mentale bilder av både muligheter og konsekvenser, og dermed en grunnleggende forutsetning for innovasjon. Det neste blir da å se litt nærmere på hvordan ulike forestillinger kan oppstå i møter mellom ulike kompetanser og kunnskapsdomener.

\section{Det å forestille seg - sammen}

Aristoteles pekte på litteraturens invitasjon til leseren om å ta stilling til et hvis eller hva om, to betingelsessubjunksjoner med stor pedagogisk og innovativ kraft. Det ligger muligheter til både refleksjon og nytenkning i kjølvannet av disse. Vi ser også at Hume sin forståelse av forestillingsevnen langt på vei samsvarer med prinsippene for inkrementell innovasjon. I en allerede realisert idé ligger kimen til nye ideer, og disse kan hentes frem og settes sammen til noe helt nytt, eksempelvis å genmanipulere et eple slik at det smaker lakris, hvis nå det skulle være av interesse. Poenget er uansett at møter mellom ulike kunnskapsdomener vil bidra til et større mangfold av muligheter og konsekvenser som kan leses ut fra det som allerede finnes: med andre ord de mulighetene som ligger i det flerstemmige (Bakhtin 1986, 1994a, 1994b, 2003). Hvis vi nå retter blikket mot tjenesteinnovasjon i helse- og omsorgssektoren, så kan ivaretakelse av pårørende være et aktuelt og beskrivende tema. I Helsedirektoratets veileder om pårørende (Helsedirektoratet, 2017) finner vi implementering av en modell for etisk refleksjon som et mulig tiltak for 
å fremme etisk bevissthet og god etisk praksis i profesjonsutøvelsen. Vi kan nå tenke oss dette tiltaket løftet inn i en undervisningssituasjon der formålet er å utfordre studentene på etiske dilemmaer. Konkret kan det dreie seg om barn som pårørende i familier med rusavhengighet. Spørsmålet er da hvordan studentene ser for seg rutiner og metoder slik at barnas behov og rettigheter ivaretas på en best mulig måte. Det å møte faglig og etisk problematikk av denne typen er praktisk talt umulig uten å forestille seg hvordan det er å være barn og pårørende av omsorgspersoner med rusproblematikk. Man vil forestille seg sorgen, skammen og den bitende lojalitetskonflikten mellom familien, egne behov og hjelpeapparatets intervenering som barnet står i. De mentale bildene studentene skaper av barnet som lever i en utfordrende omsorgssituasjon, kan oppstå av tematikken i seg selv, av eksempler og historier fra det virkelige liv, konstruerte eksempler eller fiksjonelle fortellinger. Poenget er at dette settes i en faglig setting der målet er å lage en modell for hvordan best mulig ivareta de etiske utfordringene og dilemmaene som ligger til problematikken. Studentene skal altså se for seg en modell der de i sin yrkesutøvelse kan bidra til etisk reflektert praksis. Med studenter fra ulike studieretninger aktualiseres ulik kunnskap, og med ulik kunnskap introduseres flere elementer som skaper dynamikk, motstand og framdrift. Legestudenten kan se for seg hvordan en slik modell bør se ut, mens psykologistudenten med sin kunnskap om gruppearbeid straks ser utfordringer rundt organisering, noe som bringer fysioterapistudenten på banen, som påpeker at barns fysiologiske utvikling bør tematiseres. Sykepleierstudenten ser for seg helsesykepleierens viktige bidrag, noe som aktualiserer barnehage, skole og helsestasjon inn i modellen. Studenten fra barnevern trekker inn lovverk, familienettverk og nærmiljø, noe som leder tankene mot bidrag fra brukerorganisasjoner og ungdomsråd. I en kollektiv og tverrprofesjonell læringsprosess kan altså studentene forestille seg ulike utfordringer, løsninger og scenarioer der det stadig kommer innspill fra forskjellige kunnskapsdomener. Dette er tverrfaglig utviklingsarbeid og tjenesteinnovasjon i virksomhet. Studentene, i samhandling med hverandre, gis altså muligheten til å utvikle en modell som ivaretar god etisk praksis i møte med sårbare brukere. 


\section{Noen ord til slutt}

Hvis det skal trekkes en grovmeislet slutning av denne drøftingen, vil den være at innovasjon ofte er resultatet av tverrprofesjonell samarbeidslæring. Innovasjon er møtet mellom ulike kunnskapsdomener, og hvor nye ideer, løsninger og muligheter oppstår i disse møtene. Det være seg arkitektenes arbeid mot et nytt operahus i Oslo eller studenter som i et tverrfaglig fellesskap prøver å tenke ut nye modeller for å organisere etiske refleksjoner i praksisfeltet. Det sentrale her er at det skjer noe i møtet mellom mennesker med ulik kunnskap, kompetanse og erfaringsbakgrunn. Det åpnes et mulighetsrom for å skape noe nytt. Elliot Eisner (1998, s. 37) peker på at mennesket har lav toleranse for en vedvarende stabilitet, særlig når dette fører til stillstand og stagnasjon. Vi ønsker å bruke våre kapasiteter, og vi søker nye utfordringer. Her ligger motivasjonen til å utvikle noe nytt, til å utvikle nye ideer. Dette gjøres i fellesskap, i møtet mellom mennesker som med sin kunnskap og ulike perspektiver bidrar til nytenkning og endring. Det motiveres også av vår evne til å forestille oss, til å se for oss nye løsninger og muligheter som ennå ikke er. Ja, vi kan spørre oss selv hvor vi ville vært uten evnen til å forestille oss. Noen har forestilt seg muligheten til folkestyre og demokrati, noen har forestilt seg muligheten til å oppdage nytt land bortenfor havets horisont, noen har forestilt seg muligheten til å lede elektrisk kraft, og noen har forestilt seg muligheten til å bruke virus i sykdomsbekjempelse. Vi kan bruke Paul Ricoeur (2002, s. 133) til å oppsummere essensen i det å skape noe nytt. I sin teori om metaforer beskriver han hvordan det i møtet mellom to semantiske felt oppstår en ny beskrivende relevans. Sammenstøtet bryter ned det opprinnelige, og opp fra disse ruinene bryter det frem ny mening og betydning. Dette er i all sin enkelhet også beskrivende for kollektive møter mellom ulike kunnskapsdomener: Noe nytt oppstår. I dette ligger også muligheten til å ivareta læringsutbytte nummer elleve. 


\section{Referanser}

Aristoteles. (2004). Poetikken. Frederiksberg: Det lille forlag.

Bakhtin, M. (1986). Speech Genres and Other Late Essays. Austin: University of Texas Press.

Bakhtin, M. (1994a). The Dialogic Imagination. I: P. Morris (red.), The Bakhtin Reader: Selected Writings of Bakhtin, Medvedev, Voloshinov, s. 74-80. London: Edward Arnold.

Bakhtin, M. (1994b). Problems of Dostoevsky's Poetics. I: P. Morris (red.), The Bakhtin Reader: Selected Writings of Bakhtin, Medvedev, Voloshinov s. 89-113. London: Edward Arnold.

Bakhtin, M. (2003). Latter og dialog: Utvalgte skrifter. Oslo: J. W. Cappelens forlag. Bateson, G. (1972). Steps to an Ecology of Mind. New York: Ballantine Books. Bollnow, O. F. (1969). Eksistensfilosofi og pedagogikk. København: Christian Ejlers Forlag.

Bruner, J. (1997). Utdanningskultur og laring. Oslo: Ad Notam forlag.

Carlsen, A., Clegg, S. \& Gjersvik, R. (2012). Idea Work. Om profesjonell kreativitet. Oslo: Cappelen Damm.

Christensen, C. M. (2015). The Clayton M. Christensen Reader. Boston (M): Harvard Business Review Press.

Cohen, M.D. \& Levinthal, D. A. (1990). Absorptive Capacity: A New Perspective on Learning and Innovation. Administrative Science Quarterly, 35(1), s. 128152. DOI: https://doi.org/10.2307/2393553

Currie, G. (1995). Image and Mind: Film, Philosophy and Cognitive Science. Cambridge: Cambridge University Press. DOI: https://doi.org/10.1017/CBO9780511551277

Det Norske Akademis ordbok. (2020). Hentet fra https://naob.no/ordbok/ id $\%$ C3\%A9

Dewey, J. (2008). A gjøre en erfaring: Fra Art as Experience (1934). Estetisk teori: En antologi. Oslo: Universitetsforlaget.

DiMaggio, P. (1997). Culture and Cognition. Annual Review of Sociology, 23, s. 263287. DOI: https://doi.org/10.1146/annurev.soc.23.1.263

Dysthe, O. (1993). Det flerstemmige klasserommet: Skriving og samtale for à lare. Oslo: Gyldendal forlag.

Eisner, E. W. (1998). The Kind of School We Need. Portsmouth, N. H.: Heinemann. 
Flavell, J. H. (1979). Metacognition and cognitive monitoring: A new area of cognitive-developmental inquiry. American Psychologist, 34(10), s. 906-911. DOI: https://doi.org/10.1037/0003-066X.34.10.906

Forskrift om felles rammeplan for helse - og sosialfagutdanninger. (2017). https:// lovdata.no/dokument/SF/forskrift/2017-09-06-1353 Hentet 01.12.2020.

Giddens, A. (1979). Central Problems in Social Theory: Action, Structure and Contradiction in Social Analysis. Berkeley: University of California Press. DOI: https://doi.org/10.1007/978-1-349-16161-4

Goffin, K. \& Mitchell, R. (2005). Innovation Management. London: Palgrave MacMillian.

Hargadon, A. B. \& Bechky, B. A. (2006). When Collections of Creatives Become Creative Collectives: A Field Study of Problem Solving at Work. Organization Science, 17(49), s. 484-500. DOI: https://doi.org/10.1287/orsc. 1060.0200

Hargadon, A. B. (2002). Brokering Knowledge: Linking Learing and Innovation. Research in Organizational Behavior, 24, s. 41-85.

DOI: https://doi.org/10.1016/S0191-3085(02)24003-4

Helsedirektoratet, (2017). Parørendeveileder. https://www.helsedirektoratet.no/ veiledere/parorendeveileder Hentet 04.12.2020.

Hume, D. (2012). A Treatise of Human Nature. http://www.gutenberg.org/ files/4705/4705-h/4705-h.htm. Hentet 04.12.2020.

Kunnskapsdepartementet. (2011). Utdanning for velferd. Samspill i praksis. (Meld. St. 13 (2011-2012)). https://www.regjeringen.no/no/dokumenter/ meld-st-13-20112012/id672836 Hentet 4.11.21

Laing, A. \& Bacevice, P. A. (2013). Using Design to Organizational Performance and Innovation in the Corporate Workplace: Implications for Interprofessional Environments. Journal of Interprofessional Care. 27(52), s. 37-45.

DOI: https://doi.org/10.3109/13561820.2013.792043

Lave, J. \& Wenger, E. (1991) Situated Learning: Legitimate Peripheral Participation. Cambridge: Cambridge University Press.

DOI: https://doi.org/10.1017/CBO9780511815355

Lewin, S. \& Reeves, S. (2011). Enacting 'Team' and 'Teamwork': Using Goffman's Theory of Impression Management to Illuminate Interprofessional Practice on Hospital Wards. Social Science \& Medicine, 72(10), s. 159-1602.

DOI: https://doi.org/10.1016/j.socscimed.2011.03.037

Miles, I. (1993). Services in the new Industrial Economy. Futures. 25(6), s. 653-672. DOI: https://doi.org/10.1016/0016-3287(93)90106-4 
Narings- og handelsdepartementet. (2009). Et nyskapende og barekraftig Norge. (Meld. St. 7 (2008-2009)).

Ogden, T. (2004). Kvalitetsskolen. Oslo: Gyldendal akademisk.

Pettersen, R. C. (2005). Kvalitetslaring i hogere utdanning. Innforing i problem - og praksisbasert didaktikk. Oslo: Universitetsforlaget.

Pettersen, R. C. (2017). Problembasert laring for studenter og larere: en introduksjon til PBL og studentaktive laringsformer. Oslo: Universitetsforlaget.

Ricoeur, P. (2002). For en almen teori om forestillingsevnen. I: M. Hermansen \& J. D. En hermeneutisk brobygger, s. 127-147. Århus: Klim.

Rommetveit, R. (1996). Laring gjennom dialog: Ei sosiokulturell sosiokognitiv tilnarming til kunnskap og laring. I: O. Dysthe (red). Ulike perspektiv pa laring og laringsforskning, s. 88-104. Oslo: Cappelens Akademiske forlag.

Sawyer, R. K. \& DeZutter, S. (2009). Distributed Creativity: How Collective Creations Emerge from Collaboration. Psychology of Aesthetics, Creativity and Arts, 3(2), s. 81-92. DOI: https://doi.org/10.1037/a0013282

Skairderud, F. (2016). Hva er mentalisering? Hentet fra https://psykologisk. no/2016/05/hva-er-mentalisering

Vygotskij, L. (2001). Tenkning og tale. Oslo: Gyldendal Norsk forlag.

Willumsen, E. (2016). Tverrprofesjonelt samarbeid i utdanning og praksis i helseog velferdssektoren. I: E. Willumsen \& A. Ødegård (red.). Tverrprofesjonelt samarbeid. Et samfunnsoppdrag, 2. utgave. Oslo: Universitetsforlaget.

Wollheim, R. (1974). Identification and imagination: The inner structure of a psychic mechanism. I: R. Wollheim (red.). Freud: A collection of critical essays, s. 172-195. New York: Anchor Books.

Zeithaml, V., Parasuraman, A. \& Berry, C. (1985). Problems and Strategies in Service Marketing. Journal of Marketing, 49(2), s. 33-46.

DOI: https://doi.org/10.2307/1251563 